\title{
Pathways into organized crime: comparing founders and joiners
}

\section{Luke Kemp $^{1} \cdot$ Sanaz Zolghadriha ${ }^{1} \cdot$ Paul Gill $^{1}$}

Published online: 12 September 2019

(C) The Author(s) 2019

\begin{abstract}
This paper outlines research on the engagement processes and pathways into organised crime (OC). In recent years research on $\mathrm{OC}$ has increased, however there is still little understanding of how individuals become engaged in OC, and specifically whether differences exist in engagement patterns between certain groups of OC offenders. A content analysis was undertaken on the auto/ biographies of one-hundred OC offenders to collect data on engagement processes. Quantitative analysis was used to identify significant differences in the engagement processes between OC offenders who join ('joiners') or form ('founders') an OC operation. The results revealed that measures pertaining to riskfactors, criminal trajectories, turning points, criminal motivations and social influences in engagement statistically differed between the groups. It was concluded that 'founders' were influenced by short-term criminal opportunities and economic considerations towards OC engagement, whilst 'joiners' were impacted more so by long-term social dynamics arising from ties and exposure to OC, such as one's parents being engaged in OC. Both groups however, directly engaged through social dynamics. The current study provides preliminary findings which increase academic and practical understanding of the OC fraternity, but also the findings offer a basis on which to target legal interventions. Additionally, the new knowledge may be instrumental for building theories of OC engagement. Specifically, it is theorised that the circumstances in how 'joiners' become engaged in OC represents a 'contagion process'.
\end{abstract}

Keywords Engagement · Founders · Joiners · Organized crime

Paul Gill

paul.gill@ucl.ac.uk

1 University College London, London, UK 


\section{Introduction}

Our empirical understanding of the pathways into organized crime is limited in two large ways: (a) its homogenous treatment of offenders and (b) access to relevant data. The umbrella category of 'organized criminal' subsumes many types of offender that can be dichotomized in a number of ways (e.g. leader/follower, violent/non-violent) and across a number of offence-specific roles (e.g. money launderer, trafficker, enforcer and so on). Despite this heterogeneity in outcome, studies tend to treat all organized criminals equally and do not disaggregate on the dependent variable. Much of this problem stems from a distinct lack of data. With few exceptions (Van Koppen et al. 2009 , for example), studies tend to rely on anecdote rather than rigorous systematic research that is typical in the study of the volume crime offender.

The need for such research is oft-noted. For example, DeLisi and Piquero's (2011) paper 'New Frontiers in Criminal Career Research' contended that the lack of organized criminal career typologies is a pressing research gap. Furthermore, the Home Office (2011a, p.8) report on the 'Future Direction of Organised Crime Research' implores researchers to provide an "overarching picture" of offender groups generally. There are many practical hurdles to research and the lack of access to systematic data looms particularly large. This is a problem shared within the terrorism studies literature. Recently however, terrorism-related articles began to make use of historiographical approaches with a particular emphasis on terrorist autobiographies (Altier et al. 2012). This study utilizes such data gathering and analytical techniques on 100 organized criminals. The overarching position is that $\mathrm{OC}$ offenders are atypical of the common criminal fraternity and are potentially also not typical as a group either. As such, this article makes contributes to the study of the organized criminal but also advances our theoretical understanding of the organized criminal by not treating them as a homogenous entity.

This paper explores whether the pathways, motives and drivers into organized crime differ dependent on whether the individual was a founder of a new organized crime group or a joiner of an already existing group. For the purpose of this paper, we define a founder as an individual who set up their own organised crime group. A joiner is defined as someone who joined a pre-existing group. Many studies examined these comparisons in analogous domains including terrorism (Post 1986; Weinberg and Eubank 1989; Merari et al. 2009), civil war (Mitchell 2004), gangs (Dmitrieva et al. 2014) and religious cults (Stark and Bainbridge 1979). The studies suggest a range of psychological and behavioural differences between founders of these groups and their leaders. This highlights the need for similar investigations within organized criminal groups.

\section{Theory}

This study is exploratory. There is very little existing theory or research to justify a hypothesis-driven confirmatory research design. The theory section instead touches upon the types of variables which are included in the analysis. These include risk factors associated with early life experiences, criminal trajectories, turning points and social influences. 


\section{Early life risk factors}

Research has revealed a multitude of risk-factors that precede criminal engagement. Farrington (1990), reporting on the Cambridge Study of Delinquent Development, found important predictors of criminality up to age thirty-two. In children aged eight to eleven, antisocial-behaviour, poor parenting, socio-economic deprivation, family deviance, hyperactivity, and school problems predicted future criminality (Farrington 1990). Most predictors differ amongst offender subgroups however; for example, Moffitt et al. (1996) illustrate that factors contributing to child onset delinquency were also prevalent in the development pathways of 'life course persistent' offenders (Moffitt et al. 2002). Furthermore, Nagin and Smith (1990) found factors solely linked to frequency of offending but not participation, such as social isolation. Other riskfactors include: neighbourhood-based deviant peer groups, community economic disadvantage, and exposure to neighbourhood violence (Ingoldsby and Shaw 2002); antisocial cognition (Walters and DeLisi 2013); and gang membership (Krohn et al. 2011). This type of research however has been criticised for providing a reductionist understanding and it is argued that, "Research on individual risk-factors has largely failed to specify in any detail the causal mechanisms that link the risk-factors to acts of crime and pathways in criminality" (Wikström and Sampson 2003, p.119). Consequently many theorists acknowledge the importance that other broader social and structural adversities have in mediating the effects of risk-factors; such as in Thornberry's (2005) interactional theory of offending.

Research on OC offending risk-factors reveals multiple themes. For example, a report using a sample of 4112 OC offenders identified that: at their inclusion offence $1 \%$ of OC offenders were under the age of eighteen, as compared to $19 \%$ of general offenders; the average age of OC offenders at their inclusion offence was thirty-two years; $95 \%$ were men; $45 \%$ of general offenders had received no prior penal sanctions, as compared to $10 \%$ of OC offenders (Francis et al. 2013). Similarly Van Koppen et al. (2010), using a sample of 746 OC offenders from the Dutch Organised Crime Monitor, and a sample of 109,719 general offenders, found: a higher percentage of OC contacts have prior judicial contacts $(84 \%)$ compared to general offenders $(65 \%)$; the average age at their criterion case is older for OC offenders; and OC offenders committed more serious offences prior to their criterion offence. Consequently, they conclude "the results from our study indicate that organized crime offenders are more serious criminals from the outset" (Van Koppen et al. 2010, p.371). Furthermore, OC offenders showed fewer disorders regarding affective/ interpersonal traits compared to Italian general offenders (Schimmenti et al. 2014).

\section{Criminal trajectories}

Research on criminal trajectories illustrate how criminal career features dictate specific courses of offending. Nagin and Land (1993) applied semi-parametric Poisson models to a criminal sample and found three criminal trajectories: high-rate chronic, low-rate chronic and adolescence-limited offenders. High-rate chronic offenders committed the most offences between ages ten to thirty-one, whereas low-rate offenders and adolescent-limited offenders committed a similar number of offences, but the latter mostly committed these before the age of twenty-two. Risk-factors at eight to 11 years, 
for all three groups included a low IQ, and a parental criminal record; however, highrate offenders were more likely to have delinquent siblings, and suffer job instability at ages sixteen to nineteen (Nagin and Land 1993). This study supports Moffitt's (1993) taxonomy of two dominant groups of offenders; life-course persistent (LCP), and adolescent-limited offenders (AL). Moffitt (1993) found risk-factors for LCP offenders included neuropsychological deficits due to family problems; whereas AL offending behaviour resulted from social dynamics. Patterson et al. (1989) also found two common trajectories; 'early starters' (equivalent to LCP offenders), and 'late starters' (equivalent to AL offenders). In support, a meta-analysis of eighty empirical studies on criminal trajectories found on average of three to five criminal groups, with most supporting LCP and AL offender groups (Piquero 2008). These studies demonstrate the importance of developmental constructs for persistent offenders, and the importance of social relations on limited offending trajectories. However OC offenders are ignored within these models, which until recently has resulted in a huge research gap.

Research on OC offender trajectories further supports OC offenders cannot be standardised as a group. Van Koppen et al. (2009) studied 854 OC offenders via a semi-parametric group model and found four criminal trajectories: adult-onset offenders $(40 \%)$, adolescent 'persisters' $(30 \%)$, no previous criminal record group $(19 \%)$, and early starters $(11 \%)$ who reflect the typical age-crime curve; among subgroups, 'nodal offenders' were disproportionately amongst the early starters and adolescent 'persisters'. Van Koppen et al. (2009) state the refutation of the age-crime curve for OC offenders reflects the unique processes involved in OC engagement. In addition, a report identified six OC trajectories, with the two most prevalent being: 'No previous sanctions' group (29\% who had an average age of thirty-seven and who had not been sanctioned 5 years prior their inclusion offence); and the 'Versatile and Very Prolific' group (23\% who had an average age of twenty-seven and received fifteen sanctions on average 5 years prior) (Francis et al. 2013). These findings confirm two observations, firstly that, in most cases, "OC offenders are not born criminals but choose to take advantage of their circumstances as a result of opportunities becoming available to them, or becoming more appealing to them compared with other alternatives" (Van Koppen et al. 2010, p.371), but secondly, and to a lesser extent, some offenders have graduated from a life of common crime. However, previous studies have primarily used official offence histories of offenders, and therefore it is questionable whether this information reflects reality. The 'dark figure' of crime hidden from official data could suggest many OC offenders begin criminality earlier than is known. Also, using initial criminal onset alone to identify trajectories ignores how some individuals may proceed into OC quicker than others.

\section{Turning points and life events}

Sampson and Laub (1990, 1993, 2003, 2005) contend that life events instigate engagement in crime and argue that social ties and salient life events can weaken or strengthen bonds to societal institutions: "Pathways to both crime and conformity are modified by key institutions of social control in the transition to adulthood" (Sampson and Laub 1993, p.304). Criminal pathways are therefore not fixed, instead so-called "turning points" change the course of life, however, these events are mediated by self-selection in criminal activity. Adding to this is Moffitt's (1993) 
elaboration of 'cumulative conituity', in which negative consequences of early delinquency can harm future life chances. Key to Sampson and Laub's (1993) argument is the dynamic process of the life course: "Whether generated by self-selection or cumulative continuity, a focus on stability is nonetheless insufficient for understanding crime in adult life course... Life is dynamic; change is clearly possible" (Sampson and Laub 2003, pp.308-309). This is in contrast to more deterministic models like Gottfredson and Hirschi's (1990) General Theory of Crime which overstates early life factors in determining criminality. Sampson and Laub (1993) found stable marriage and stable employment were instrumental in desistance, whereas prison sentences and unstable jobs led to criminality. Thus, there appears to be a clear understanding among scholars that turning points are important when understand the course of general criminal careers. The idea of turning points may thus fundamental to building an understanding of $\mathrm{OC}$ engagement.

Life events research reveals what directly initiates criminal engagement. Byrne and Trew (2008, p.238) found in participant interviews that pathways into crime "were shaped by a range of personal and social background influences and by processes related to negative social relations, positive evaluations of crime, and crime orientation”. Byrne and Trew (2008) identified four groups of triggers of criminal engagement: lifestyle changes; responses to early delinquency; positive offending experiences; and background disadvantage. A plethora of research supports that change in life circumstances impacts criminal engagement. For example: cohabiting with a wife doubled the odds of offending desistance, whereas during drug use there was a fifteen-fold increase in drug crimes (Horney et al. 1995); also negative life events triggered criminality in non-offending adults (Engdahl 2015). Research has also highlighted the importance of life circumstances and reputation enhancement in criminal engagement (Emler and Reicher 1995; Carroll et al. 2003). Exemplifying life event research, Blokland and Nieuwbeerta (2005) studied criminal careers over a six- year period using official data of 4615 offenders and self-report data from 2244 individuals, and found that life circumstances impact offending groups differently, yet life circumstances significantly impact offending probability.

Less research has been conducted on turning points associated with OC engagement per se, with previous research preferring an analysis of the impact of the social relations of life circumstances in OC engagement. Van Koppen (2013) studied Dutch criminal investigations of 314 offenders from fifteen crime groups, and argued Social Capital Theory best explains OC engagement as it operates through mutual gain for both parties; the OC group gains the individual's assets whilst the group assists the individual to meet personal goals. Finding suitable co-offenders is important to ensure trust and reliability, thus Van Koppen (2013) found that in nearly all the crime groups studied, family and friendship ties between offenders were present; when individuals became engaged outside of family ties and friendship they often had contacts and specialised knowledge through their occupations or previous criminality. In regard to motivation, monetary gain and improving social status were highly valued; also, negative life events such as financial setback, and family problems sparked criminal motivation (Van Koppen 2013). On the other hand, Firestone (1993) used a content analysis of Mafia memoirs to identify engagement pathways. Firestone (1993) found that Sutherland's (1947) Differential Association Theory which explains criminality as a behaviour learnt through social interactions, best describes OC engagement. Firestone 
(1993) explained that the impact Mafia role-models had on individuals' attitudes and aspirations whilst growing up in Mafia dominated neighbourhoods. Again, these studies are limited as homogeneity amongst offenders is assumed, and therefore this study will explore tunring points in OC engagement.

\section{Social influences}

The previous section highlighted the importance of social ties in criminal engagement. In support, Wright et al. (2001) using data from the Dunedin Study found the direct effects of low self-control were weaker in influencing criminal behaviour than for indirectly influencing engagement through anti-social ties; thus, it is the dynamic social relationships that drive criminal propensity in these individuals. Many scholars argue that for OC engagement however, social relations are more important.

Albanese (2000) vied in his model that for OC to occur three elements must come together: criminal opportunity factors; a criminal environment (available offenders); and criminal skills. The existence of a criminal environment is in some ways the most important factor leading to engagement. Kleemans and Van De Bunt (1999) support this, through the notion of the 'social embeddedness' of OC; they analogise this process as a 'snowball effect' whereupon certain social relations allow contact with criminal associates, in turn criminal individuals depend on these associations for resources, however eventually the dependency weakens and they choose their own path, where upon this, potential criminals are attracted to them as a result, and the cycle continues. Kleemans and Van De Bunt (2008) further support the importance of social ties by indicating how work relations within certain occupations and settings allow OC activity; they demonstrate how transport and logistic businesses straddle the licit and illicit boundaries giving rise to criminal associations and opportunities.

A study by Kleemans and De Poot (2008) gives further credence to the importance of a 'social opportunity structure' in OC; using a Dutch sample of 979 suspects on trial from 1995 to 1999 , they exposed that the 'social opportunity structure' explains the parameters in which offenders progress to and within OC; especially why there are a disproportionate amount of 'late-starters' involved in OC, and why OC offenders are older in general. In their 'starters' sample (those individuals who had recently moved into OC), Kleemans and De Poot (2008) found some had specialised skills attained through previous careers allowing criminal co-offending, whereas many 'nodal-offenders' did not have criminal pasts, and the majority (54\%) were 20 years or older upon their first judicial contact. Social ties are important because of the greater logistical nature of $\mathrm{OC}$ and consequently there is a higher value put on trust and reliance (Kleemans and de Poot 2008), thus finding the right co-offenders is imperative to the success of the operation. The importance of social ties is also highlighted in engagement processes of piracy in Somalia (Gjelsvik and Bjørgo 2012); and for knowledge transfer and co-offending amongst cybercriminals (Hutchings 2014). These findings led Kleemans (2013) to argue that although economic motives may explain $\mathrm{OC}, \mathrm{OC}$ is not co-ordinated by economic principles, but rather by social structures.

Building on Firestone's (1993) content analysis approach, this paper will analyse OC auto/biographies to gain a more thorough picture into the criminal pathways and engagement processes present amongst OC offenders, as well as to uncover motivations which Van Koppen (2013) argues stay unexposed in official data. The 
current paper will provide a statistical basis to these findings, addressing a limitation of Firestone (1993) and Van Koppen (2013).

\section{Methodology}

\section{Data}

The data for the current study was collected through a content analysis of biographies and autobiographies of individuals that have been engaged in OC. Biographies in various forms have been used to understand criminality, such as for female offenders (Carlen 1985), and the lives of prisoners (Morgan 1999). In terrorist research the analysis of biographies has produced findings on recruitment processes, and motivations (Shapiro and Siegel 2012; Teymur 2007; Gill et al., 2018). Although there are many limitations to auto/biographies, which are discussed later, the current method "can only hope to provide a more in-depth level of insight into men's lives as criminals" (Goodey 2000, p.494).

Biographies also cover seminal events in an individual's life and thus provide an optimal source to examine life processes such as OC engagement. Autobiographical information is heavily reliant on autobiographical memory. Autobiographical memory plays a critical role in the construction of individual identity, accounting for what occurs, and when in a lifespan. Given this, systematic analysis of autobiographies has the potential to offer understanding of criminal life-span. Critical analysis of autobiographical information allows for examination of underlying behavioral processes over a life course, an advantage not afforded in prevalence studies (Altier et al. 2012; Altier et al. 2017). Analysis of autobiographical data also limits participant reactivity via; removal of contamination effects found in observation studies, elimination of researcher-participant interactions, removal of expectancy bias from participants, and reduction of artificiality found in interview designs (Altier et al., 2017; Krippendorff 2004). Despite weaknesses, there are merits to using autobiographical data to investigate terrorist behavior. Reminiscence bumps (Rubin et al. 1998) occur in autobiographical memory recall due to the novelty and stability of event onset occurring in early adulthood. Events occurring in early adulthood have a higher chance of autobiographical recall in later life (Conway and Pleydell-Pearce 2000; Pillemer et al. 1988; Rubin et al. 1998).

A sample of one-hundred individuals previously engaged in $\mathrm{OC}$ was collected from a total of eighty-three texts (some books tracked the lives of multiple individuals); thirty-three of these were autobiographies, and fifty-five were biographies. All the texts were print sources published in English and available in the UK. The list is in thef appendix. Furthermore, an entirely male sample was compiled due to the minimal availability of biographies on females engaged in OC; a representative sample of females was thus unachievable.

Given the finite number of (auto)biographies available on such matters a convenience sampling method was used to attain the texts. However, the biographies were scrutinised as to whether the individual's criminal activities reflected the following definition:

"Organised crime involves individuals, normally working with others, with the capacity and capability to commit serious crime on a continuing basis, which includes 
elements of planning, control and coordination, and benefits those involved. The motivation is often, but not always, financial gain." (Home Office 2011b, p.5).

This definition has been used for previous research reports (Francis et al. 2013) that have provided interesting findings in the UK, but it is also broad enough to form a valid basis in the collection of an international sample of OC offender (auto)biographies.

\section{Data coding}

Life events, circumstances and forces regarding and leading to the commission of crime were recorded. Furthermore, key non-criminal life events were also recorded; these events usually entailed changes in life circumstances and transition periods. A specific focus was given to criminal pathways and $\mathrm{OC}$ engagement however these were not exclusively focused upon.

The coding process was iterative; therefore, once a new concept arose, the previously coded texts were re-read to check for the presence of emerging concepts. This process was repeated until the coding schedule reflected all the possible events and processes that were defined as important in the texts. Essentially this is the process of 'category saturation' in Strauss and Corbin's (1990) Grounded Theory approach.

Dey (1993) claims that a content analysis relies upon the researcher's interpretation of the data, and then their interpretation on how to code it when creating categories; this is partly true however due to the nature of the (auto)biographies, part of the coding has already been completed by the author of the text in that what is highlighted as important is demonstrated by its presence in the text. Consequently, this allows some objectivity when approaching a content analysis on this form of media. Nevertheless, for some concepts, for example the transition into OC, some biographies explicitly stated its occurrence, however in other cases the research team made inferences about the circumstances of the individual's criminal engagement given the context of the prose.

For most of the variables recorded the data was input dichotomously in the form of binary code, where a ' 1 ' reflected the presence of the variable, and a ' 0 ' reflected its absence. It is important to highlight that ' 0 ' did not suggest that the measure did not exist in the individual's life, but rather it was not present in the text. Some variables were qualitative as they reflected nuances that could not be initially collected dichotomously, however these were individually assessed and any themes amongst these were re-coded into dichotomous categories. Some continuous data was also recorded, such as the age of the individual at various life events.

In total the coding of the texts led to the creation of one-hundred and seventy-five variables. The coding reflects a chronology of the individual's life until engagement and thus the main areas, of which the variables were grouped, as in the (auto)biographies, were early life and environment, early criminal careers, and engagement with OC.

Kleemans and De Poot (2008) analysed the differences amongst 'starters', and 'nodal offenders' in their analysis of the 'social opportunity structures' of OC. In a similar fashion the current study analysed the differences amongst OC criminals who form a criminal operation ('founders') and those who join ('joiners'). It is assumed different engagement pathways and processes will be prevalent for both groups, as inferred by differences found in the trajectory studies of OC offenders (Van Koppen et al. 2009). 


\section{Limitations to consider}

Prior to the analysis stage, it is important to acknowledge the limitations inherent in the data used in this study. The data used in this study is derived from biographies and autobiographies, which raises potential limitations to reliability and validity of sources. First, readers should be aware that the sample may not be a fair representation of the general organised crime population. The data will therefore be analysed with the acknowledgement that the results represent a sample of individuals who chose to share their experiences. Second, the sample may also be over-respresntative of individuals who started their criminal career early, and had a long career. These may have been more likely to write a book about their experiences, rather than those who started late and therefore had a shorter career. In conjunction to this, the authors are also aware that the late starters with short careers may be under-represented in the current dataset. However, the current study is an exploration of pathways into organised crime through openly available data. We are therefore not aiming to map a general understanding of the topic. Third, as the data is based on self-reported information, it is acknowledged that the authors of the books may have self-justified their actions. A potential pitfall of self-report, in the nature of these books, is the distortion of information for the benefit of the author. We are aware that authors may enhance information for the purpose of 'selling' books, and therefore the extracted data will be analyised with caution.

Since the validity and reliability of the data will be under scrutiny, it is important to highlight the effect this may have on the analysis ahead. As described above, the data collection will follow the procedure of content analysis. Content analysis relies on the objective and systematic coding approach of the researcher. The coding process of this study was completed under a structured method, to ensure consistency. However, the authors acknowledge that the information extracted may be a product of the coder.

The above mentioned limitations will be further discussed in conjunction with the results, as part of the Discussion section of this paper.

\section{Analysis}

There were two stages of data analysis; firstly bivariate analysis, using Chi-square was undertaken between the chosen dependent variable (DV) and independent variables (IV), to examine the significance of the relationship between the variables. Given the variables have been recorded dichotomously Chi-square is appropriate because it is a non-parametric test. To measure the strength of the association the Phi-coefficient was calculated also; Phi is appropriate only for two-by-two tables and therefore suitable for dichotomous data.

Secondly binary logistic regressions (BLR) were computed to reveal predictive relationships between the IVs found to be significant from the Chi-Square analysis and the chosen DV. As highlighted by Herrenkohl et al. (2000), one important reason BLR's are more effective than multivariate regressions in highlighting predictive risk-factors on a DV, is because many risk constructs are highly correlated. Additionally, Hill et al. (1999) contend that it is important to compute the odd ratios, which are more appropriate to present predictive results due to sample size concerns, and base rate issues.

A two-step approach was taken due to the large number of variables collected. Therefore it was more informative to analyse which variables were significant, compute 
the direction of the association, group them accordingly, and subsequently analyse how well they predict an outcome via a BLR. Also the statistical analysis package, SPSS V.21, has a limit to the number of covariates that can be included in a BLR.

In the instance where means testing took place, normality checks were undertaken and the appropriate parametric/nonparametric tests were used. In the current paper the Shapiro-Wilk test was used to check for distribution normality because it is appropriate for samples with less than two thousand cases.

\section{Results}

The all-male multinational sample $(n=100)$ was compromised of: $48 \%$ American citizens, of which 32 individuals were of Italian descent; $37 \%$ British citizens of which 11 identified as Scottish; 5\% Italian citizens; and the rest of the sample was made up of cases from: Belorussia (1\%), Canada(1\%), Columbia(1\%), Finland(1\%), Ireland (3\%), Japan(1\%), and Mexico (2\%). Of the sample $92 \%$ would be considered ethnically White Caucasian.

Categorising seminal OC offences $(n=100)$ shows $28 \%$ were involved in violent offences upon their seminal OC crime, (including contracted murders, and enforcing for OC groups); $24 \%$ became involved in trafficking/transit crimes (including drug distribution, and bootlegging); $22 \%$ were involved in organised acquisitive crimes (including armed robberies, and hijackings); $18 \%$ started their OC careers with Racketeering offences (including protection rackets, and loansharking); and $8 \%$ became engaged in 'Other' crimes (including fraud, and cases where individuals joined an OC operations without the commission of a criminal offence).

Chi-square analysis was used to identify risk-factors prior OC engagement, which were significantly associated with forming or joining an OC operation.

Those variables found to be significantly associated with joining (as opposed to forming) an OC group are listed in Table 1. They include a range of familial and neighbourhood risk factors as well as social benefits. These results indicate that joiners often have at least one family member (whether parents, immediate, or non-immediate) who is connected to organised crime activities, and that they lived in neighbourhoods with a clear criminal code. Further, the analysis highlights the importance of social connections for joining organised crime, either through role models engaged in organised crime or other prior social ties to organised crime.

Variables found to be significantly associated with forming an OC group are listed in Table 2. Typically, most of the variables involve some form of prior non-OC criminality and are reflective of a longer pattern of criminal activity. As illustrated in Table 2, founders are characterised by their previous involvement in criminal activities, and at times their personal direct connection to organised crime or criminal gangs. Thus, these results suggest that founders have established a foundational knowledge on criminal activities, prior to founding their own criminal organisation.

Because of this cluster of findings, we then analysed the relationship between age and the onset of OC and non-OC criminal offending. The results (in Fig. 1) are indicative of the fact that $\mathrm{OC}$ engagement does not follow the typical age-crime curve but largely occurs later during the individual's non-OC criminal career.

The interval time period (in years) between onset of non-OC criminal offending and becoming engaged in $\mathrm{OC}$ is also different between the two sub-sets. 'Joiners' had an 
Table 1 'Risk-factors' associated with joining OC

\begin{tabular}{lllll}
\hline Variable & Chi-square & DF & $P$ Value $\leq$ & Phi-Coefficient \\
\hline The individual's parents were engaged in OC. & 11.741 & 1 & 0.001 & -0.343 \\
The individual's parents had social ties with OC offenders. & 10.553 & 1 & 0.001 & -0.325 \\
Non-immediate family were engaged in OC. & 4.125 & 1 & 0.05 & -0.203 \\
OC groups operated in their youth neighbourhood & 8.243 & 1 & 0.01 & -0.287 \\
A criminal code was apparent in their youth neighbourhood. & 5.803 & 1 & 0.05 & -0.241 \\
The individual had OC role models prior to adulthood. & 11.511 & 1 & 0.001 & -0.339 \\
The individual had OC social ties prior engagement & 13.765 & 1 & 0.001 & -0.371 \\
Incurred social benefits from OC Social ties. & 4.225 & 1 & 0.05 & -0.206 \\
Incurred economic benefits from OC Social ties. & 4.398 & 1 & 0.05 & -0.210 \\
Committed crimes requested by OC & 5.593 & 1 & 0.05 & -0.236 \\
$\quad$ offender prior engagement. & & & & \\
\hline
\end{tabular}

average of 9.06 years difference between criminal onset and OC engagement, and 'founders' had an average of 12.90 years. A comparison of means test outlined this difference to be significant $(\mathrm{U}=352, \mathrm{Z}=-1.972, p \leq 0.05)$. 'Founders' had an average rank of 36.77, whereas 'joiners' had an average rank of 27.67.

Fifteen of the cases highlighted a turning point towards OC engagement that centred around a negative life event. $73 \%$ of these events included criminal imprisonment, $20 \%$ included financial setback, and 7\% included death of a relative. A Chi-square analysis revealed that these variables were more significantly associated with the formers of organized criminal groups (Table 3 ).

In terms of motivations for either forming or joining an OC group, the formers were significantly more likely to provide economic narratives in their outline of their decision-making (Table 4).

There were also significant differences in terms of the mechanisms through which individuals became associated with OC groups. Joiners were significantly more likely to rely upon pre-existing ties, formal introductions (often through family connections) and formal invitations to join (Table 5).

Table 2 'Risk-factors' associated with forming OC

\begin{tabular}{lllll}
\hline Variable & Chi-square & DF & $P$ Value $\leq$ & Phi-Coefficient \\
\hline $\begin{array}{l}\text { Involved in criminal gangs during childhood } \\
\quad \text { and/or adolescence }\end{array}$ & 6.598 & 1 & 0.01 & 0.257 \\
Prior crimes brought economic rewards & 15.763 & 1 & 0.001 & 0.397 \\
Proceeds from crime funded further criminal activity & 19.828 & 1 & 0.001 & 0.445 \\
Pursued higher criminal profits after a successful criminal act & 15.564 & 1 & 0.001 & 0.395 \\
Criminal contacts expanded as a result of crime & 10.721 & 1 & 0.001 & 0.327 \\
In prison individual socialised with OC criminals & 6.573 & 1 & 0.01 & 0.256 \\
In prison individual underwent criminal learning & 10.726 & 1 & 0.001 & 0.328 \\
\hline
\end{tabular}




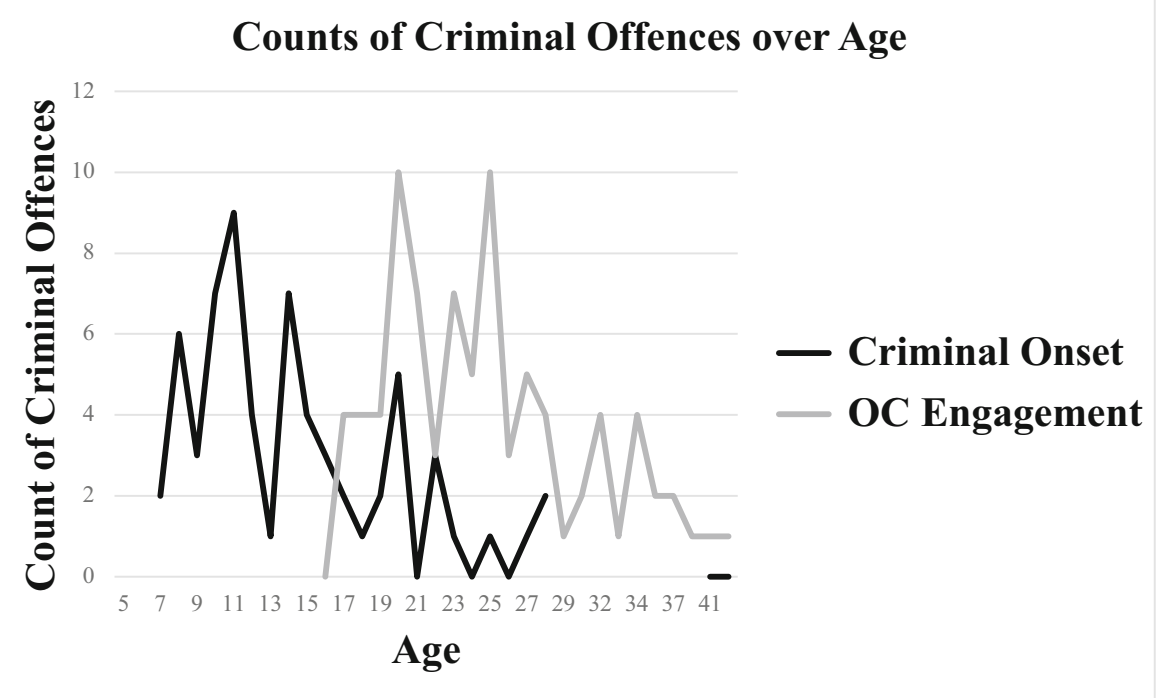

Fig. 1 Counts of offender age at criminal onset and OC engagement

Founders, on the other hand, were significantly more likely to refer to international criminal links and engagement alongside previous non-OC criminals (Table 6).

These findings indicate both joining and forming an $\mathrm{OC}$ operation are based on social relations with other criminals, for example 'joiners' are 'Introduced into OC by an OC offender', whereas 'founders' are more likely to engage 'alongside previous criminal contacts'.

\section{Regression analysis}

As illustrated in Table 7, the binary logistic regression (BLR) revealed that, when combined, the independent variables found to be associated with forming an OC operation (identified in the Chi-square analysis) were significant in impacting an individual forming an OC operation $\left(\mathrm{X}^{2}(12)=58.853, p \leq 0.001\right)$. The model predicted $81 \%$ of cases correctly, rising from $56 \%$. Two variables were significantly predictive of forming: 1)' Engagement resulting from a criminal opportunity'; and 2) 'OC engagement alongside previous criminal contacts'. Respectively they were 14.14 , and 3.18 times more likely to predict forming than joining in offenders.

Table 3 Turning points associated with forming OC

\begin{tabular}{lllll}
\hline Variable & Chi-square & DF & $P$ Value $\leq$ & Phi Coefficient \\
\hline Engagement resulted from a negative life event & 6.162 & 1 & 0.05 & 0.248 \\
Engagement resulted from a criminal opportunity & 12.227 & 1 & 0.001 & 0.350 \\
\hline
\end{tabular}


Table 4 Motivations associated with forming OC

\begin{tabular}{lllll}
\hline Variable & Chi-square & DF & $P$ Value $\leq$ & Phi-Coefficient \\
\hline Engagement motivation was for economic reasons & 10.721 & 1 & 0.001 & 0.327 \\
\hline
\end{tabular}

A second $\mathrm{BLR}^{1}$ (See Table 8.) revealed the IVs associated with joining were significant in impacting whether individuals joined an OC operation $\left(\mathrm{X}^{2}(14)\right.$ $=63.377, p \leq 0.001$ ). The model predicted $86 \%$ of cases correctly, rising from $56 \%$. Two variables were found to be significant predictors of joining: 1) 'Introduced into OC by an OC offender'; and 2) 'Invited to form/join OC operation due to criminal reputation'. Respectively they were 6.61 , and 11.33 times more likely to predict joining than forming.

\section{Discussion}

The results collectively point to the same conclusion that $\mathrm{OC}$ engagement mechanisms, pathways and processes, differ amongst OC 'joiners' and 'founders'. In summary OC engagement in 'joiners' seems more subtle reflecting long-term processes and developmental social factors, a 'natural progression' as such. However, for 'founders' the processes affecting engagement are short-term and more transient reflecting true opportunities. This is similar to the differences observed in Moffitt's (1993) and Patterson et al. (1989) life course offenders (developmental causes) and limited offending (social causes) taxonomies; yet for OC, 'joiners' are impacted by developmental social dynamics, whereas 'founders' are impacted by arising opportunities. These findings suggest taxonomies of engagement mechanisms and pathways could be built from understanding the long and short-term engagement processes.

Furthermore the long-term impacts of $\mathrm{OC}$ exposure on 'joiners' represents a contagion like process. This is similar in essence to Kleemans and Van De Bunt's (1999) snowball effect, but we argue social ties and exposure to OC, not only influence OC engagement through socio-cultural mechanisms more than economic considerations, but also speed up engagement as shown by the age interval differences. The basis is 'Differential Association' as Firestone (1993) suggests. However, the analogy of contagion is used for 'joiners' as the motivations to pursue OC 'infects' individuals and neighbourhoods surreptitiously depending on the extent of exposure to OC. Ultimately the closer one is to OC the more likely they are to join. These overall conslusions are discussed in detail in the next section.

The results illustrate the plurality of paths and processes involved in OC engagement amongst offenders. Research on risk-factors of criminality have usually highlighted early life circumstances as seminal in future criminal careers (Farrington 1990), and in the current study, albeit with different results, similar risk-factors were found in

\footnotetext{
${ }^{1}$ Accurate odd-ratios and confidence intervals could not be calculated for the variable 'The individual's parents were engaged in OC'. This is possibly due to too low frequencies in sample numbers for this variable; however it was included because it added positively to the predictability of the model.
} 
Table 5 Engagement mechanisms associated with joining OC

\begin{tabular}{lllll}
\hline Variable & Chi-square & DF & $P$ Value $\leq$ & Phi-Coefficient \\
\hline Existing social ties with OC groups upon OC engagement & 9.976 & 1 & 0.01 & -0.316 \\
Introduced into OC by an OC offender & 35.065 & 1 & 0.001 & -0.592 \\
Introduced into OC due to family connections & 9.982 & 1 & 0.01 & -0.316 \\
Invited to form/join OC operation due to criminal reputation & 25.163 & 1 & 0.001 & -0.502 \\
\hline
\end{tabular}

'joiners' and to a lesser extent 'founders'. Issues such as deprivation, social class, and poor parenting, although present in the sample, were not associated with either joining or forming.

For 'joiners' risk-factors included family involvement in OC, OC role models, OC groups operating in youth neighbourhood, and a criminal code in the local neighbourhood. ${ }^{2}$ From a theoretical perspective it seems 'joiners' go through a developmental process of lifelong OC socialisation as Firestone (1993) suggests, or a process where the cumulative exposure to $\mathrm{OC}$ impacts the individuals chances of becoming involved. The significant presence of OC role models and OC groups in the local neighbourhoods of the 'joiners' sample is indicative of Differential Association Theory (Sutherland 1947) which argues criminal behaviour is learnt through criminal role models. In support one OC offender, Philip Leonetti contended "I was born into this life, the Mafia, La Cosa Nostra. It was inevitable for me. It was literally in my blood" (Leonetti et al. 2012, p.24). Alternatively it could be argued that joining occurs purely due to the lack of opportunities to form an OC operation within areas with existing OC groups. This idea is in turn supported by the binary logistic regression (BLR) findings, as no risk-factors were found to be significant predictors of joining.

In contrast 'founders' are impacted more by later life risks and opportunities built from common criminal careers. Significant associations were found between forming and factors such as expanding criminal networks, making profit from crime, and criminal learning during imprisonment. However, a BLR showed that none of these risk factors were found to predict forming; this suggest that there is a need to understand the role of other factors, and that a larger sample is needed. Nevertheless, our findings does support Sampson and Laub's (1993) theory on the impacts of turning points, especially in the 'founders' sample. The results indicate that as crime becomes lucrative, and the individual forms criminal networks, criminal propensity in 'founders' increases until OC engagement is reached. However, as noted by Farrington (2003, p.225): "the distinction between risk-factors and life events is not clear-cut, because some life events may be continuing experiences whose duration is important (e.g. marriage or a job), while some risk-factors may occur at a particular time (e.g., loss of a parent)". Therefore it is important to understand risk-factors and turning points in most cases are 'two sides of the same coin' and thus some variables in the current study are not mutually exclusive.

\footnotetext{
$\overline{2}$ This concept was coded on the basis that many individuals noted their neighbourhoods, for example, refused to cooperate with the police, sorted disputes internally, and deferred to local OC groups.
} 
Table 6 Engagement mechanisms associated with forming OC

\begin{tabular}{lllll}
\hline Variable & Chi-square & DF & $P$ Value $\leq$ & Phi-Coefficient \\
\hline International criminal links developed OC engagement & 7.429 & 1 & 0.01 & 0.273 \\
Engagement alongside previous criminal contacts & 18.204 & 1 & 0.001 & 0.427 \\
\hline
\end{tabular}

Age of criminal onset was found to range from childhood to adulthood which indicates support for Van Koppen et al. (2009) OC offender trajectories. However, criminal onset was not significantly associated with age at $\mathrm{OC}$ engagement, and mean ages of OC engagement differed minimally across criminal onset age periods, suggesting that other factors are significant in OC engagement, beyond the predictability of criminal onset. Average age at $\mathrm{OC}$ engagement suggests life course events during the mid-twenties are more dominant in impacting OC engagement than events prior to adulthood. Nevertheless it is clear for OC offenders there are better measures, than criminal onset, to investigate criminal trajectory.

The interval period between criminal onset and OC engagement was significantly different for 'founders' and 'joiners'. The results showed that 'joiners' moved into OC from criminal onset significantly quicker than 'founders'. Considering that 'joiners' had higher associations with factors of $\mathrm{OC}$ exposure, the analysis infers the greater precedence of 'social opportunity structures' in OC engagement, due to the presence of OC structures in their locality (Kleemans and de Poot 2008). Alternatively, since 'founders'

Table 7 Logistic regression predicting odds of forming OC

\begin{tabular}{|c|c|c|c|c|c|}
\hline Variable & $\mathrm{B}$ & Wald & SE & Odds-Ratio & $95 \% \mathrm{CI}$ \\
\hline $\begin{array}{l}\text { Involved in criminal gangs during childhood } \\
\text { and/or adolescence }\end{array}$ & 0.386 & 0.314 & 0.689 & 1.472 & $0.381-5.681$ \\
\hline Prior crimes brought economic rewards & 1.072 & 1.636 & 0.838 & 2.921 & $0.565-15.092$ \\
\hline $\begin{array}{l}\text { Proceeds from crime funded further } \\
\text { criminal activity }\end{array}$ & 1.447 & 3.070 & 0.826 & 4.250 & $0.842-21.448$ \\
\hline $\begin{array}{l}\text { Pursued higher criminal profits after } \\
\text { a successful criminal act }\end{array}$ & -0.727 & 0.714 & 0.860 & 0.483 & $0.090-2.610$ \\
\hline Criminal contacts expanded as a result of crime & 0.952 & 2.040 & 0.667 & 2.591 & $0.701-9.572$ \\
\hline In prison individual socialised with OC criminals & -0.313 & 0.067 & 1.204 & 0.732 & $0.069-7.744$ \\
\hline In prison individual underwent criminal learning & 1.787 & 1.644 & 1.393 & 5.969 & $0.389-91.598$ \\
\hline Engagement resulting from a negative life event & 0.719 & 0.411 & 1.121 & 2.051 & $0.228-18.460$ \\
\hline Engagement resulting from a criminal opportunity & 2.649 & 5.695 & 1.110 & $14.136^{*}$ & $1.605-124.475$ \\
\hline Engagement motivation was for economic reasons & -0.353 & 0.231 & 0.733 & 0.703 & $0.167-2.959$ \\
\hline $\begin{array}{l}\text { International criminal links developed } \\
\text { OC engagement }\end{array}$ & 1.155 & 1.369 & 0.987 & 9.495 & $2.504-36.008$ \\
\hline $\begin{array}{l}\text { Engagement alongside previous } \\
\text { criminal contacts }\end{array}$ & 2.251 & 10.954 & 0.680 & $3.175^{* *}$ & $0.458-21.995$ \\
\hline
\end{tabular}

$\mathrm{n}=100 ; \mathrm{B}=$ Regression Coefficient $\mathrm{SE}=$ Standard Error $\mathrm{CI}=$ Confidence Interval;

$* p \leq 0.05, * * p \leq 0.01$ 
Table 8 Logistic regression predicting odds of joining OC

\begin{tabular}{|c|c|c|c|c|c|}
\hline Variable & B & Wald & SE & Odds-Ratio & $95 \% \mathrm{CI}$ \\
\hline The individual's parents were engaged in OC & 20.476 & 0.000 & $10,063.862$ & $781,254,710.7$ & $0.000-$ \\
\hline $\begin{array}{l}\text { The individual's parent's had social ties with } \\
\text { OC offenders }\end{array}$ & 0.298 & 1.309 & 1.388 & 0.204 & $0.013-3.102$ \\
\hline Non-immediate family were engaged in $\mathrm{OC}$ & -0.305 & 0.048 & 1.356 & 1.347 & $0.094-19.222$ \\
\hline $\begin{array}{l}\text { OC crime groups operated in their youth } \\
\text { neighbourhood }\end{array}$ & -0.305 & 0.110 & 0.921 & 0.737 & $0.121-4.485$ \\
\hline $\begin{array}{l}\text { A criminal code was apparent in their youth } \\
\text { neighbourhood }\end{array}$ & 0.884 & 1.092 & 0.845 & 2.420 & $0.461-12.688$ \\
\hline $\begin{array}{l}\text { The individual had OC role models } \\
\text { prior to adulthood. }\end{array}$ & -0.203 & 0.043 & 0.974 & 0.816 & $0.121-5.511$ \\
\hline $\begin{array}{l}\text { The individual had OC social ties } \\
\text { prior engagement }\end{array}$ & 0.938 & 0.650 & 1.164 & 2.556 & $0.261-25.031$ \\
\hline Incurred social benefits from OC social ties & -0.972 & 0.650 & 1.205 & 0.379 & $0.036-4.017$ \\
\hline $\begin{array}{l}\text { Incurred economic benefits from } \\
\text { OC Social ties }\end{array}$ & 0.566 & 0.276 & 1.077 & 1.762 & $0.213-14.557$ \\
\hline $\begin{array}{l}\text { Committed crimes requested by OC offenders } \\
\text { prior engagement }\end{array}$ & -1.139 & 1.768 & 0.857 & 0.320 & $0.060-1.716$ \\
\hline $\begin{array}{l}\text { Existing social ties with OC groups upon } \\
\text { OC engagement }\end{array}$ & 0.288 & 0.082 & 0.795 & 1.256 & $0.264-5.966$ \\
\hline Introduced into $\mathrm{OC}$ by an $\mathrm{OC}$ offender & 1.888 & 6.938 & 0.717 & $6.605 * *$ & $1.621-26.914$ \\
\hline Introduced into $\mathrm{OC}$ due to family connections & 2.607 & 2.991 & 1.507 & 13.556 & $0.706-260.175$ \\
\hline $\begin{array}{l}\text { Invited to form/join OC operation due to } \\
\text { criminal reputation }\end{array}$ & 2.428 & 0.766 & 10.055 & $11.334 * *$ & $2.527-50.828$ \\
\hline
\end{tabular}

$\mathrm{n}=100 ; \mathrm{B}=$ Regression Coefficient $\mathrm{SE}=$ Standard Error; $\mathrm{CI}=$ Confidence Interval;

$* * p \leq 0.01$

are not associated with having OC groups in their locality, it is suggested they have to wait to exploit OC opportunities, shown by the higher precedence of risk-factors denoting the economics of crime.

As already highlighted, the findings support the notion of turning points (Sampson and Laub 1993) and that they differ for 'joiners' and 'founders'. Although the research highlights that there are no variables implicit of turning points associated with joining OC, many variables were not mutually exclusive. Therefore, for 'joiners' a 'turning point' could represent the significant association with earlier risk-factors; such as having an OC role model. Chi-square results revealed 'founders' were more likely to become engaged in $\mathrm{OC}$ due to a negative life experience. These events included imprisonment, death of a relative, and financial setback. The circumstances of how such scenarios led to OC engagement most likely differ for each event; for example imprisonment is most likely associated with criminal learning, as shown by the significant association between forming and criminal learning, and the binding of OC social ties in prison. Furthermore, engagement of 'founders' resulting from a criminal opportunity was significantly associated and a significant predictor, and was fourteen times more likely to result in an individual forming an $\mathrm{OC}$ operation. This again 
highlights the importance of short-term opportunities in the process of OC engagement for 'founders' as compared to the long-term effects of OC exposure on 'joiners'. These findings largely support two of Byrne and Trew's (2008) four triggers of (common crime) criminal engagement: lifestyle changes, and positive offending experiences.

The motivation for OC is different for 'founders' compared to 'joiners'. Although the BLR showed being motivated by economic gains was not a significant predictor of forming, it was still significantly associated with forming. This consequently supports previous findings of this paper that pathways and engagement mechanisms between 'founders' and 'joiners' differ on multiple paradigms; and primarily that 'founders' are more influenced and motivated by the appearance and changes in short-term opportunities than 'joiners', who seem to be motivated by developmental socialisation issues.

\section{Conclusion}

The previous literature suggests engagement in OC usually results from social structures, and social opportunities (Kleemans and Van De Bunt 1999; Kleemans and de Poot 2008; Kleemans and Van de Bunt 2008; Kleemans 2013; Van Koppen et al. 2009, 2010; Van Koppen 2013). The current study confirms and furthers these findings. Of the four significant associations between joining and OC engagement mechanisms, two were found to be significant predictors. Firstly, 'joiners' were more likely to be introduced into OC crime by a pre-existing OC offender, which supports Kleemans and Van De Bunt's (1999) notion of the 'social embeddedness' of OC. Secondly, 'joiners' were more likely to be invited to form/join OC due to their previous criminal reputation, agreeing with the argument that $\mathrm{OC}$ requires the recruitment of suitable co-offenders, who can be trusted and relied upon (Kleemans and de Poot 2008; Van Koppen 2013).

However, unlike the previous literature (Kleemans and Van de Bunt 2008) work relations were not predominant factors in $\mathrm{OC}$ engagement. Also, both variables were the only two significant predictors of joining; this insinuates that possibly joining or forming $\mathrm{OC}$ is more impacted by immediate engagement mechanisms than prior criminal pathways or risk-factors.

'Founders' engagement mechanisms also reflected social dynamics; however these ties were based on common criminal networks rather than OC networks. An offender progressing into OC alongside common criminal associates was found to be a significant predictor of, and three times more likely, to result in forming. This reaffirms that 'founders' take advantage of open criminal opportunities, whereas 'joiners' are subject to the social dynamics of OC in their locality. Nevertheless, 'founders' exploitation of criminal opportunities still relies on social relations, but with common criminal contacts, not OC contacts. This is highlighted in how the creation of international criminal contacts preceded OC engagement for 'founders'. On the other hand, joining OC is exemplified by the following quote; "I had a reputation for fighting with my hands, so moving from boxing, to bouncing, to working for Jimmy was a natural progression for me" (Weeks and Karas 2006 p.64). Furthermore one Mafia boss noted that growing up in a Mafia neighbourhood and consequently moving into OC was, "the natural order of things" (Carlo 2008, p.43). 
Limitations to the study should be highlighted however. Content analyses are limited in that the strength and validity of the results are heavily reliant on the authenticity, credibility and representativeness of the source documents (Scott 1990), and as such "a content analysis can only be as good as the documents on which the practitioner works" (Bryman 2008, p.291). The sources were a mix of autobiographies and biographies; although to a greater extent for autobiographies, both rely on the memory of primarily human sources. Consequently this questions the 'authenticity' of the information recalled, and whether it represents what it purports to be. Studies have shown issues of memory confabulation in old age, and that information overlearning of episodic memory events impinges on the memory recall of other events (Barba et al. 2010). Consequently, this impact on writers of (auto)biographies and their sources seriously brings to question the validity of such media.

A further concern is the 'credibility' of the sources, which Scott (1990) claims is the extent to which the content of the document has been distorted. Shipman (1997) suggests (auto)biographies are self-justifying; in these circumstances events are often glamorised. Again this is more of an issue for autobiographies than biographies, however authors in most cases are trying to make a profit through interesting and exciting reads, thus the authenticity of these documents are a serious concern. We see no reason however why this factor should be more of a case in one of our sub-samples as opposed to the other.

An additional limitation is that of 'representativeness', which concerns whether the context of the text can be generalised (Scott 1955). In the current study it is questionable whether the criminals of focus in the (auto)biographies are representative of OC offenders without auto/biographies. Altier et al. (2012) makes this point in relation to terrorist autobiographies; they contend biases may exist in the motivations of these individuals, or the characteristics amongst them. Nevertheless unless interviews are undertaken with OC offenders who do not have (auto)biographies then this issue cannot be ameliorated.

The content analysis method itself is limited primarily in regard to the coding of the data; as Bryman (2008, p.291) contends "It is almost impossible to devise coding manuals that do not entail some interpretation on part of coders". Being objective and coding concepts to the point of theoretical saturation requires the coder to make decisions in what the data is signifying and then accordingly group concepts into categories. Concerns thus arise in questioning the validity of the coding categories the coder has created. In the current study, since only one coder was conducting the research, the issue at hand is intra-coder reliability, which questions whether the individual's coding behaviour is consistent over time. However, as of yet, statistical tests confirming intra-coder reliability are still in their infancy (Gwet 2008). Given issues concerning the coding process and the consequent trustworthiness of the data, Elo and Kyngäs (2008) suggest a thorough description of how the data links to the results is essential, of which this study has tried to achieve.

A final concern lies in the limited demographic scope of the sample. There are very few texts written on female OC offenders, and most of the texts available are written on white British or American OC offenders. Possibly with time more diverse texts may be published, however currently this research paper is limited by the choices of publishing agencies, and thus this limitation should not reflect the sampling method chosen by the researcher. 


\section{Appendix: List of biographical sources used for the current research}

Anastasia, G. (1991). Blood and Honor: Inside the Scarfo Mob, the Mafia's Most Violent Family. New York: W. Morrow.

Attwood, S. (2013). Party Time. Croydon: Mainstreem Publishing.

Barnes, L., \& Folsom, T. (2008). Mr. Untouchable: The Rise and Fall of the Black Godfather. Wrea Green: Milo.

Barnes, T., Elias, R., \& Walsh, P. (2001). Cocky: The Rise and Fall of Curtis Warren, Britain's Biggest Drug Baron. Bury: Milo.

Beith, M. (2010). The Last Narco: Inside the Hunt for El Chapo, the World's Most Wanted Drug Lord. New York: Grove.

Blatchford, C. (2008). The Black Hand: The Bloody Rise and Redemption of "Boxer" Enriquez, a Mexican Mob Killer. New York: Morrow.

Birkbeck, M. (2013). The Quiet Don: The Untold Story of Mafia Kingpin Russell Bufalino. New York, NY: Berkley.

Bonanno, J., \& Lalli, S. (1983). A Man of Honour: The Autobiography of a Godfather. London: Deutsch.

Breslin, J.(2009). The Mafia Rat: A True Story. Edinburgh: Mainstream.

Campbell, L., \& Edward, P. (2013). Satan's Choice: My Life as an Outlaw Biker with Satan's Choice and Hells Angels. London: Sidgwick \& Jackson.

Capeci, J., \& Mustain, G. (2012). Gotti: The Rise and Fall. London: Ebury.

Capeci, J., \& Robbins, T. (2013). Mob Boss: The Life of Little Al D'Arco, the Man Who Brought down the Mafia. New York: St Martin's.

Carlo, P. (2006). The Ice Man: Confessions of a Mafia Contract Killer. New York: St. Martin's.

Carlo, P. (2008). Gaspipe: Confessions of a Mafia Boss. New York: William Morrow. Carlo, P. (2009). The Butcher: Anatomy of a Mafia Psychopath. New York, NY: William Morrow.

Carr, H. (2011). Hitman: The Untold Story of Johnny Martorano: Whitey Bulger's Enforcer and the Most Feared Gangster in the Underworld. New York: Forge.

Chepesiuk, R. (2010). The Trafficantes: Godfathers from Tampa, Florida: The Mafia, the CIA, and the JFK Assassination. La Vergne, TN: Strategic Media.

Clarkson, W. (2004). Moody: The Life and Crimes of Britain's Most Notorious Hitman. Edinburgh: Mainstream.

Clarkson, W. (2006). Kenny Noye: Public Enemy Number 1. London: John Blake.

Clarkson, W. (2009). Billy Hill: Godfather of London. London: Pennant.

Crittle, S. (2006). The Last Godfather: The Rise and Fall of Joey Massino. New York: Berkley.

Ciancimino, M., \& La Licata, F. (2012). Don Vito and the Mafia: Living with My Father's Secrets. London: Quercus.

Courtney, D. (1999) Stop the Ride, I Want to Get Off: An Autobiography. London: Virgin. Davidson, E., \& Pyle, J. (2005) Joey Pyle: Notorious: The Changing Face of Organised Crime. London: Virgin.

DeStefano, A. (2006). King of the Godfathers. New York: Kensington.

DeStefano, A.(2011). Mob Killer. New York: Pinnacle /Kensington.

DeStefano, A. (2013). Vinny Gorgeous: The Ugly Rise and Fall of a New York Mobster.

Conneticut: Lyons press. 
Donnelly, J. (2013). Jimmy the Weed: Inside the Quality Street Gang: My Life in the Manchester Underworld. Wrea Green: Milo.

English, T. J. (2006). The Westies: Inside New York's Irish Mob. New York: St. Martin's Griffin.

Escobar, R. (2009). Escobar. London: Hodder.

Falcus, D. (2007). Gangland to God. Goring-by-Sea: Verité.

Forwell, M., \& Bullman, L. (2010). Blowback. London: Pan.

Findlay, R. (2012). Caught in the Crossfire. Edinburgh: Birlinn.

Ferris, P., \& McKay, R. (2001). The Ferris Conspiracy. Edinburgh: Mainstream.

Foreman, F. (2009). Freddie Foreman: The Godfather of British Crime. London: John Blake.

Foreman, J. (2012). Jamie Foreman: Gangsters, Guns and Me. London: John Blake.

Franzese, M. (2003). Blood Covenant: The Michael Franzese Story. New Kensington, PA.: Whitaker House.

Fraser, F., \& Morton, J. (1994). Mad Frank: Memoirs of a Life of Crime. London: Warner. Giancana, S., \& Burnstein, S. (2010). Family Affair: Treachery, Greed, and Betrayal in the Chicago Mafia. New York: Berkley.

Griffin, D. \& Arnoldy, D. (2007). Cullotta: The Life of a Chicago Criminal, Las Vegas Mobster, and Government Witness. Las Vegas, NV: Huntington.

Griffin, D., \& A DiDonato, A. (2010). Surviving the Mob: A Street Soldier's Life inside the Gambino Crime Family. Las Vegas: Huntington.

Jeffrey, R. (2003). Glasgow's Godfather: The Astonishing inside Story of Walter Norval, the City's First Crime Boss. Edinburgh: Black \& White.

Joey, \& Fisher, D. (2002). Joey the Hitman: The Autobiography of a Mafia Killer. New York, NY: Thunder's Mouth.

Johnson, G. (2007). The Devil: Britain's Most Feared Underworld Taxman. Edinburgh: Mainstream.

Kivisalo, R., \& Joensuu, M. (2010). The Red Scorpion: The True Story of a Ruthless Russian Mob Boss's Dramatic Redemption. Grand Rapids, MI: Chosen.

Lacey, R. (1991). Little Man: Meyer Lansky and the Gangster Life. Boston: Little, Brown. Lambrianou, T., \& Clerk, C. (2009). Inside the Firm: The Untold Story of the Krays' Reign of Terror. London: John Blake.

Leach, C. (2009). Rise of the Footsoldier. London: John Blake.

Lehr, D., \& O’Neill, G. (2013). Whitey: The Life of America's Most Notorious Mob Boss. USA: Crown Publishers.

Leonetti, P., Burnstein, S., \& Graziano, C. (2012). Mafia Prince: Inside America's Most Violent Crime Family and the Bloddy Fall of La Cosa Nostra. Philadelphia: Running. Longrigg, C. (2008). Boss of Bosses. London: John Murray.

Lucas, F., \& King, A. (2010). Original Gangster: The Real Life Story of One of America's Most Notorious Drug Lords. New York: St. Martin's.

MacDonald, I., \& Leslie, D. (2012). Blink. Edinburgh: Mainstream.

Marks, H. (1997). Mr Nice. London: Minerva.

McKay, R. (2006). The Last Godfather: The Life and Crimes of Arthur Thompson. Edinburgh: Black \& White Pub.

McKay, R. (2010) McGraw: The Incredible Untold Story of Tam 'the Licensee' McGraw. Edinburgh: Black \& White. 
Mooney, J. (2008). Gangster: The Biography of John Gilligan. Dunshaughlin: Maverick House.

Mustain, G., \& Capeci, J. (1992). Murder Machine. New York: Dutton.

Newark, T. (2012). Lucky Luciano: Mafia Murderer and Secret Agent. Edinburgh: Mainstream.

O’Connor, M. (2013). The Dealer: Smuggling Drugs on the Costa Del Crime. Wrea Green: Milo.

O’Neill, G., \& Lehr, D. (1989). The Underboss: The Rise and Fall of a Mafia Family. New York: St. Martin's.

Pearson, J. (2001). The Cult of Violence: The Untold Story of the Krays. London: Orion. Pearson, J. (2003). One of the Family: The Englishman and the Mafia. London: Century. Pileggi, N., (1985). Wiseguy: Life in a Mafia Family. New York: Simon and Schuster. Polisi, S., \& Dougherty, S. (2012). The Sinatra Club. New York: Gallery.

Porter, B. \& Jung, G. (2001). Blow: How a Small-town Boy Made 100 Million Dollars with the Meddelin Cocaine Cartel and Lost It All. New York: St Martin's.

Pridmore, J., \& Watts. (2002). From Gangland to Promised Land. London: Darton Longman and Todd.

Pritchard, A., \& Parker, N. (2008). Urban Smuggler. Edinburgh: Mainstream.

Reynolds, B. (1995). The Autobiography of a Thief. London: Bantam.

Richardson, C. (2013). Charlie Richardson: The Last Gangster: The Final Confession. London, UK: Century.

Roemer, W. (1994). The Enforcer: Spilotro, the Chicago Mob's Man over Las Vegas. New York: Donald I. Fine.

Roemer, W. (1995). Accardo: The Genuine Godfather. New York: D.I. Fine.

Saga, J,. \& Bester, J. (1995). Confessions of a Yakuza: A Life in Japan's Underworld. Tokyo: Kodansha.

Saggio, F., \& Rosen, F. (2004). Born to the Mob: The True-life Story of the Only Man to Work for All Five of New York's Mafia Families. New York: Thunder's Mouth.

Sicario., Molloy, M. \& Bowden, C. (2011). El Sicario: The Autobiography of a Mexican Assassin. New York: Nation.

Shalhoup, M. (2010). BMF: The Rise and Fall of Big Meech and the Black Mafia Family. New York: St. Martin's.

Shannon, A., \& Leslie, D. (2011). The Underworld Captain: From Gangland Goodfella to Army Officer. Edinburgh: Mainstream Pub.

Smith, G. (2003). Made Men: The True Rise-and-fall Story of a New Jersey Mob Family. New York: Berkley.

Tippett, J., \& Stow, N. (2014). Born Gangster. UK: John Blake.

Weeks, K., \& Karas, P. (2006). Brutal: The Untold Story of My Life inside Whitey Bulger's Irish Mob. New York: Regan.

Williams, P. (2003). The General: Irish Mob Boss. New York: Forge/A Tom Doherty Associates Book.

Wilson, J., \& Findlay, R. (2010). The Iceman: The Rise and Fall of a Crime Lord. Edinburgh: Birlinn.

Whiting, R. (1999). Tokyo Underworld: The Fast times and Hard Life of an American Gangster in Japan. New York: Pantheon. 
Open Access This article is distributed under the terms of the Creative Commons Attribution 4.0 International License (http://creativecommons.org/licenses/by/4.0/), which permits unrestricted use, distribution, and reproduction in any medium, provided you give appropriate credit to the original author(s) and the source, provide a link to the Creative Commons license, and indicate if changes were made.

\section{References}

Albanese JS (2000) The causes of organized crime: do criminals organize around opportunities for crime or do criminal opportunities create new offenders? J Contemp Crim Justice 16(4):409-423

Altier MB, Horgan J, Thoroughgood C (2012) In their own words? Methodological considerations in the analysis of terrorist autobiographies. J Strat Secur 5(4):11

Altier MB, Leonard Boyle E, Shortland ND, Horgan JG (2017) Why they leave: An analysis of terrorist disengagement events from eighty-seven autobiographical accounts. Secur Stud 26(2):305-332

Barba GD, Attali E, La Corte V (2010) Confabulation in healthy aging is related to interference of overlearned, semantically similar information on episodic memory recall. J Clin Exp Neuropsychol 32(6):655-660

Blokland AA, Nieuwbeerta P (2005) The effects of life circumstances on longitudinal trajectories of offending. Criminology 43(4):1203-1240

Bryman A (2008) Social research methods, 3rd edn. Oxford University Press, Oxford

Byrne CF, Trew KJ (2008) Pathways through crime: the development of crime and desistance in the accounts of men and women offenders. Howard J Crim Just 47(3):238-258

Carlen P (1985) Criminal women. Polity Press, Cambridge

Carlo P (2008) Gaspipe: confessions of a mafia boss. William Morrow, New York

Carroll A, Green S, Houghton S, Wood R (2003) Reputation enhancement and involvement in delinquency among high school students. Int J Disabil Dev Educ 50(3):253-273

Conway MA, Pleydell-Pearce CW (2000) The construction of autobiographical memories in the self-memory system. Psychol Rev 107(2):261

DeLisi M, Piquero AR (2011) New frontiers in criminal careers research, 2000-2011: a state-of-the-art review. J Crim Just 39(4):289-301

Dey I (1993) Qualitative data analysis. A User-Friendly Guide for Social Scientists. Routledge, London

Dmitrieva J, Gibson L, Steinberg L, Piquero A, Fagan J (2014) Predictors and consequences of gang membership: comparing gang members, gang leaders, and non-gang-affiliated adjudicated youth. J Res Adolesc 24(2):220-234

Elo S, Kyngäs H (2008) The qualitative content analysis process. J Adv Nurs 62(1):107-115

Emler N, Reicher S (1995) Adolescence and delinquency: the collective management of reputation. Hobokan, Blackwell Publishing

Engdahl O (2015) White-collar crime and first-time adult-onset offending: explorations in the concept of negative life events as turning points. Int J Law Crime Justice 43(1):1-16

Farrington DP (1990) Implications of criminal career research for the prevention of offending. J Adolesc 13(2):93-113

Farrington DP (2003) Developmental and life-course criminology: key theoretical and empirical issues-the 2002 Sutherland award address*. Criminology 41(2):221-225

Firestone TA (1993) Mafia memoirs: what they tell us about organized crime. J Contemp Crim Justice 9(3): $197-220$

Francis B, Humphreys L, Kirby S, Soothill K (2013) Understanding criminal careers in organised crime. London: Home Office

Gill P, Marchment Z, Corner E, Bouhana N (2018) Terrorist decision making in the context of risk, attack planning, and attack commission. Studies in Conflict \& Terrorism 1-16

Gjelsvik IM, Bjørgo T (2012) Ex-pirates in Somalia: processes of engagement, disengagement, and reintegration. J Scand Stud Criminol Crime Prev 13(2):94-114

Goodey J (2000) Biographical lessons for criminology. Theor Criminol 4(4):473-498

Gottfredson MR, Hirschi T (1990) A general theory of crime. Stanford University Press.

Gwet KL (2008) Intrarater reliability. In: D’Agostino RB, Sullivan L, Massaro J (eds) Wiley. Encyclopaedia of Clinical Trials (4 volume set). New York, Wiley. Retrieved from: http://www.agreestat.com/research papers/wiley_encyclopedia2008_eoct631.pdf. Accessed 12 Dec 2017 
Herrenkohl TI, Maguin E, Hill KG, Hawkins JD, Abbott RD, Catalano RF (2000) Developmental risk-factors for youth violence. J Adolesc Health 26(3):176-186

Hill KG, Howell JC, Hawkins JD, Battin-Pearson SR (1999) Childhood risk-factors for adolescent gang membership: results from the Seattle social development project. J Res Crime Delinq 36(3):300-322

Home Office (2011a) Future Direction for Organised Crime Research. Retrieved from: https://www.gov. uk/government/uploads/system/uploads/attachment_data/file/116653/future-organised-crime-res-2011.pdf. Accessed 29 Aug 2019

Home Office (2011b) Local to Global, Reducing the Risk from Organised Crime. Retrieved from: https://www.gov.uk/government/uploads/system/uploads/attachment_data/file/97823/organised-crimestrategy.pdf. Accessed 29 Aug 2019

Horney J, Osgood DW, Marshall IH (1995) Criminal careers in the short-term: intra-individual variability in crime and its relation to local life circumstances. Am Sociol Rev 60:655-673

Hutchings A (2014) Crime from the keyboard: organised cybercrime, co-offending, initiation and knowledge transmission. Crime Law Soc Chang 62(1):1-20

Ingoldsby EM, Shaw DS (2002) Neighborhood contextual factors and early-starting antisocial pathways. Clin Child Fam Psychol Rev 5(1):21-55

Kleemans ER (2013) Organized crime and the visible hand: a theoretical critique on the economic analysis of organized crime. Criminol Crim Just 13(5):615-629

Kleemans ER, de Poot CJ (2008) Criminal careers in organized crime and social opportunity structure. Eur J Criminol 5(1):69-98

Kleemans ER, Van De Bunt HG (1999) The social embeddedness of organized crime. Transnational Organized Crime 5(1):19-36

Kleemans ER, Van de Bunt HG (2008) Organised crime, occupations and opportunity. Global Crime 9(3): 185-197

Krippendorff K (2004) Reliability in content analysis. Hum Commun Res 30(3):411-433

Krohn MD, Ward JT, Thornberry TP, Lizotte AJ, Chu R (2011) The cascading effects of adolescent gang involvement across the life course. Criminology 49(4):991-1028

Leonetti P, Burnstein S, Graziano C (2012) Mafia prince: inside America's Most violent crime family and the Bloddy fall of La Cosa Nostra. Running, Philadelphia

Merari A, Diamant I, Bibi A, Broshi Y, Zakin G (2009) Personality characteristics of "self martyrs"/"suicide bombers" and organizers of suicide attacks. Terrorism Polit Violence 22(1):87-101

Mitchell N (2004) Agents of atrocity: leaders, followers, and the violation of human rights in civil war. London, Springer

Moffitt TE (1993) Adolescence-limited and life-course-persistent antisocial behavior: a developmental taxonomy. Psychol Rev 100(4):674-701

Moffitt TE, Caspi A, Dickson N, Silva P, Stanton W (1996) Childhood-onset versus adolescent-onset antisocial conduct problems in males: natural history from ages 3 to 18 years. Dev Psychopathol 8(2): 399-424

Moffitt TE, Caspi A, Harrington H, Milne BJ (2002) Males on the life-course-persistent and adolescencelimited antisocial pathways: follow-up at age 26 years. Dev Psychopathol 14(1):179-207

Morgan S (1999) Prison lives: critical issues in reading prisoner autobiography. Howard J Crim Just 38(3): $328-340$

Nagin DS, Smith DA (1990) Participation in and frequency of delinquent behavior: A test for structural differences. J Quant Criminol 6(4):335-356

Nagin DS, Land KC (1993) Age, criminal careers, and population heterogeneity: specification and estimation of a nonparametric, mixed Poisson model. Criminology 31(3):327-362

Patterson GR, DeBaryshe BD, Ramsey E (1989) A developmental perspective on antisocial behaviour. Am Psychol 44(2):329-335

Pillemer DB, Goldsmith LR, Panter AT, White SH (1988) Very long-term memories of the first year in college. J Exp Psychol Learn Mem Cogn 14(4):709

Piquero AR (2008) Taking stock of developmental trajectories of criminal activity over the life course. In: The long view of crime: a synthesis of longitudinal research. Springer, New York, pp 23-78

Post JM (1986) Hostilité, conformité, fraternité: the group dynamics of terrorist behavior. Int J Group Psychother 36(2):211-224

Rubin DC, Rahhal TA, Poon LW (1998) Things learned in early adulthood are remembered best. Mem Cogn 26(1):3-19

Sampson RJ, Laub JH (1990) Crime and deviance over the life course: the salience of adult social bonds. Am Sociol Rev 55:609-627 
Sampson RJ, Laub JH (1993) Turning points in the life course: why change matters to the study of crime*. Criminology 31(3):301-325

Sampson RJ, Laub JH (2003) Life-course desisters? Trajectories of crime among delinquent boys followed to age 70. Criminology 41(3):555-592

Sampson RJ, Laub JH (2005) A life-course view of the development of crime. Ann Am Acad Polit Soc Sci 602(1):12-45

Schimmenti A, Caprì C, La Barbera D, Caretti V (2014) Mafia and psychopathy. Crim Behav Ment Health 24(5):321-331

Scott WA (1955) Reliability of content analysis: The case of nominal scale coding. Public Opin Q 321-325

Scott J (1990) A matter of record: documentary sources in social research. Polity Press, Cambridge

Shapiro JN, Siegel DA (2012) Moral hazard, discipline, and the management of terrorist organizations. World Polit 64(01):39-78

Shipman M (1997) The limitations of social research, Fourth Edition, Boston, Addison Wesley Longman Ltd

Stark R, Bainbridge WS (1979) Of churches, sects, and cults: preliminary concepts for a theory of religious movements. J Sci Study Relig 18:117-131

Strauss, A., \& Corbin, J. M. (1990). Basics of qualitative research: grounded theory procedures and techniques. Thousand Oaks, Sage Publications, Inc.

Sutherland EH (1947) Principles of criminology, 4th edn. Lippincott, Philadelphia

Teymur, S. (2007). A conceptual map for understanding the terrorist recruitment process: observation and analysis of DHKP/C, PKK, and Turkish Hezbollah terrorist organizations. Unpublished dissertation. University of North Texas: Denton, Texas, USA. Retrieved from: http://digital.library.unt.edu/ark:/67531 /metadc3914/m2/1/high_res_d/dissertation.pdf. Accessed 29 Aug 2019

Thornberry TP (2005) Explaining multiple patterns of offending across the life course and across generations. Ann Am Acad Polit Soc Sci 602(1):156-195

Van Koppen MV (2013) Involvement mechanisms for organized crime. Crime Law Soc Chang 59(1):1-20

Van Koppen MV, De Poot CJ, Kleemans ER, Nieuwbeerta P (2009) Criminal trajectories in organized crime. Br J Criminol 50:102-123

Van Koppen MV, De Poot CJ, Blokland AA (2010) Comparing criminal careers of organized crime offenders and general offenders. Eur J Criminol 7(5):356-374

Walters GD, DeLisi M (2013) Antisocial cognition and crime continuity: cognitive mediation of the past crime-future crime relationship. J Crim Just 41(2):135-140

Weeks K, Karas P (2006) Brutal: the untold story of my life inside whitey Bulger's Irish mob. Regan, New York

Weinberg L, Eubank W (1989) Leaders and followers in Italian terrorist groups. Terrorism Polit Violence 1(2): $156-176$

Wikström POH, Sampson RJ (2003) Social mechanisms of community influences on crime and pathways in criminality. In: Causes of conduct disorder and juvenile delinquency, vol 118, p 152

Wright BRE, Caspi A, Moffitt TE, Silva PA (2001) The effects of social ties on crime vary by criminal propensity: a life-course model of interdependence. Criminology 39(2):321-348

Publisher's note Springer Nature remains neutral with regard to jurisdictional claims in published maps and institutional affiliations. 